\title{
Methyl Internal Rotation Fine Structure in the Ground State Rotational Spectrum of Gauche Butane
}

\author{
Kirsten Vormann and Helmut Dreizler \\ Abteilung Chemische Physik im Institut für Physikalische Chemie der Universität Kiel \\ Hans Hübner and Wolfgang Hüttner \\ Universität Ulm, Abteilung Chemische Physik
}

Z. Naturforsch. 45a, 989-994 (1990); received May 18, 1990

\begin{abstract}
The methyl torsional fine structure in the rotational spectrum of gauche butane in the vibrational ground state was investigated in the frequency range between 10 and $141 \mathrm{GHz}$. Using the internal axis method (IAM) in the formulation of Woods, all internal rotation parameters were determined with high accuracy. The barrier height of the methyl internal rotation was determined to 11.34 (29) $\mathrm{kJ} / \mathrm{mol}(2.710(69) \mathrm{kcal} / \mathrm{mol})$
\end{abstract}

Key words: gauche-butane, hindered rotation, methyl group, barrier height, rotational spectrum.

\section{Introduction}

n-Butane exists in two stable rotational conformers, the non-polar low energetic trans and the high energetic gauche form. The energy difference $\Delta H$, determined with different methods by several authors [1-6], seems to decrease by at least $0.6 \mathrm{~kJ} \cdot \mathrm{mol}^{-1}$ when the gas passes through the phase transition into the liquid state. Using the most recent gas-phase result, $\Delta H=2.94 \mathrm{~kJ} \cdot \mathrm{mol}^{-1}[6]$, one calculates relative gauche-butane concentrations of $32 \%$ at $-30^{\circ} \mathrm{C}$ and of $24 \%$ at $-80^{\circ} \mathrm{C}$ in a sample cell under microwave spectroscopical low-density conditions. A detailed consideration shows that rovibrational cooling overcomes concentration losses into the trans state down to temperatures as low as $-170^{\circ} \mathrm{C}$ [7].

The gauche-butane molecule belongs to the point group $\mathrm{C}_{2}$ where its twofold symmetry axis coincides with the principal inertia $b$-axis. Hence it shows only $b$-type rotational transitions, and the methyl groups are equivalent by symmetry. The rotational spectrum of gauche-butane was first observed in the mm-wave range and assigned by Hüttner, Majer, and Kästle [8]. They determined the electric dipole moment, the rotational constants, all quartic centrifugal distortion constants in Watson $A$ reduction [9] and some of the sextic constants. The electric dipole moment of the molecule, $\mu_{b}$, is $0.0900(15) \mathrm{D}$.

Reprint requests to Prof. Dr. H. Dreizler, Institut für Physikalische Chemie der Universität Kiel, Olshausenstr. 40-60, D-2300 Kiel.
Some mm-wave K-doublets were found to be split in three or more components [8]. Though hindered internal rotation of the methyl gropus must be considered as the most important origin of these fine structures, there is also a slight probability that gauchegauche dihedral tunnelling of the $\mathrm{C}_{2} \mathrm{H}_{5}$ groups might have some influence. Several experimental [10] and computational $[11,12]$ attempts have been made to determine the dihedral potential function of the n-butane system which partly resulted in considerable disagreement of the barrier heights. The present contribution aims at the experimental determination of the methyl barrier, but is also thought to ensure whether or not dihedral effects add to the splittings of the ground-state transitions of the molecule.

\section{Experimental}

The sample of butane was obtained commercially from Merck, Darmstadt, chemical purity $>99.5 \%$.

The fine structure splittings of 45 rotational transitions, listed in Table 1, were investigated, 20 of them are in the frequency region between 10 and $38 \mathrm{GHz}$, 10 in the range between 57 and $63 \mathrm{GHz}$ and the remaining 15 in the $\mathrm{mm}$ region between 113 and $141 \mathrm{GHz}$.

The spectra of the first group were recorded with the microwave Fourier transform (MWFT) spectrometers at Kiel [13-15]. These transitions were measured at temperatures between -30 and $-50^{\circ} \mathrm{C}$ and pres-

0932-0784 / $90 / 0800-0989 \$ 01.30 / 0$. - Please order a reprint rather than making your own copy. 
Table 1. Transitions of gauche-butane showing internal rotation fine structure. $\Gamma$ : symmetry species, $v$ : experimental frequency, $\Delta v$ : experimental internal rotation splitting, $\delta$ : difference between experimental and calculated splitting, $v_{0}$ : hypothetical center frequency, $u$ : estimated uncertainty (in kHz) of $\Delta v$ used for calculating the weighting factor $\left.W_{i}^{1}\right) . J K_{-} K_{+}$designates the lower, $J^{\prime} K_{-}^{\prime} K_{+}^{\prime}$ the upper rotational level.

\begin{tabular}{|c|c|c|c|c|c|c|c|c|c|c|c|c|c|c|c|c|c|c|c|c|c|}
\hline \multicolumn{5}{|c|}{$J^{\prime} K_{-}^{\prime} K_{+}^{\prime}-J K_{-} K_{+}$} & \multirow{2}{*}{$\begin{array}{l}\Gamma \\
\mathrm{AA} \\
\mathrm{EE}\end{array}$} & \multirow{2}{*}{$\begin{array}{l}\begin{array}{l}v \\
{[\mathrm{MHz}]}\end{array} \\
140971.500 \\
140971.920\end{array}$} & \multirow{2}{*}{$\begin{array}{l}\begin{array}{l}\Delta v \\
{[\mathrm{MHz}]}\end{array} \\
-0.420\end{array}$} & \multirow{2}{*}{$\begin{array}{l}\delta \\
{[\mathrm{kHz}]} \\
\\
-34\end{array}$} & \multirow{2}{*}{$\begin{array}{l}\frac{v_{0}}{[\mathrm{MHz}]} \\
140971.418\end{array}$} & \multirow{2}{*}{$\begin{array}{l}u \\
{[\mathrm{kHz}]}\end{array}$} & \multicolumn{5}{|c|}{$J^{\prime} K_{-}^{\prime} K_{+}^{\prime}-J K_{-} K_{+}$} & $\Gamma$ & $\begin{array}{l}v \\
{[\mathrm{MHz}]}\end{array}$ & \multirow{2}{*}{$\begin{array}{l}\Delta v \\
{[\mathrm{MHz}]}\end{array}$} & $\begin{array}{l}\delta \\
{[\mathrm{kHz}]}\end{array}$ & \multirow{2}{*}{$\begin{array}{l}\begin{array}{l}v_{0} \\
{[\mathrm{MHz}]}\end{array} \\
131105.365\end{array}$} & \multirow{2}{*}{$\begin{array}{l}u \\
{[\mathrm{kHz}}\end{array}$} \\
\hline 7 & 5 & $2-6$ & 4 & 3 & & & & & & & 17 & 8 & $9-17$ & 7 & 10 & $\begin{array}{l}\mathrm{AA} \\
\mathrm{EE}\end{array}$ & $\begin{array}{ll}131 & 105.461 \\
131 & 105.783\end{array}$ & & 9 & & \\
\hline 9 & 1 & $8-9$ & 0 & 9 & $\begin{array}{l}\mathrm{AA} \\
\mathrm{EE} \\
\mathrm{AE}\end{array}$ & $\begin{array}{ll}31 & 531.308 \\
31 & 531.246 \\
31 & 531.184\end{array}$ & $\begin{array}{l}0.062 \\
0.124\end{array}$ & $\begin{array}{l}-2 \\
-3\end{array}$ & 31531.225 & (5) & & & & & & $\begin{array}{l}\text { EE* } \\
\mathrm{EA} \\
\mathrm{AE}\end{array}$ & $\begin{array}{ll}131 & 104.673 \\
131 & 105.943 \\
131 & 105.337\end{array}$ & $\begin{array}{r}0.788 \\
-0.482 \\
0.124\end{array}$ & $\begin{array}{r}-26 \\
6 \\
-34\end{array}$ & & \\
\hline & & & & & $\mathrm{EA}$ & 31531.184 & 0.124 & -3 & & & 17 & 2 & $15-17$ & & 16 & $\mathrm{AA}$ & 59220.275 & & & 59220.109 & (8) \\
\hline 10 & 1 & $9-10$ & 0 & 10 & $\begin{array}{l}\mathrm{AA} \\
\mathrm{EE} \\
\mathrm{AE}\end{array}$ & $\begin{array}{l}37037.210 \\
37037.133 \\
37037.057\end{array}$ & $\begin{array}{l}0.077 \\
0.153\end{array}$ & $\begin{array}{l}2 \\
4\end{array}$ & 37037.108 & (5) & & & & & & $\begin{array}{l}\mathrm{EE} \\
\mathrm{AE} \\
\mathrm{EA}\end{array}$ & $\begin{array}{l}59220.146 \\
59220.029 \\
59220.029\end{array}$ & $\begin{array}{l}0.129 \\
0.246 \\
0.246\end{array}$ & $\begin{array}{r}4 \\
-4 \\
-4\end{array}$ & & \\
\hline & & & & & $\mathrm{EA}$ & 37037.057 & 0.153 & 4 & & & 17 & 8 & $10-17$ & 7 & 11 & $\mathrm{AA}$ & 131107.129 & & & 131107.014 & (20) \\
\hline 11 & 2 & $9-11$ & 1 & 10 & $\begin{array}{l}\mathrm{AA} \\
\mathrm{EE} \\
\mathrm{AE}\end{array}$ & $\begin{array}{l}28059.960 \\
28059.911 \\
28059.865\end{array}$ & $\begin{array}{l}0.049 \\
0.095\end{array}$ & $\begin{array}{r}1 \\
-1\end{array}$ & 28059.896 & (5) & 18 & 7 & $12-17$ & 8 & 9 & $\begin{array}{l}\mathrm{EE} \\
\mathrm{AA} \\
\mathrm{EE}\end{array}$ & $\begin{array}{r}131106.621 \\
28582.481 \\
28581.904\end{array}$ & 0.577 & 11 & 28582.540 & (5) \\
\hline & & & & & $\mathrm{EA}$ & 28059.865 & 0.095 & -1 & & & 18 & 8 & $10-18$ & 7 & 11 & $\mathrm{AA}$ & 130908.851 & & & 130908.748 & (20) \\
\hline 12 & 5 & $8-11$ & 6 & 5 & $\begin{array}{l}\mathrm{AA} \\
\mathrm{AE} \\
\mathrm{EE}\end{array}$ & $\begin{array}{l}10074.004 \\
10074.101 \\
10073.639\end{array}$ & $\begin{array}{r}-0.097 \\
0.365\end{array}$ & $\begin{array}{r}-9 \\
0\end{array}$ & 10074.063 & (5) & & & & & & $\begin{array}{l}\mathrm{EE} \\
\mathrm{EE}^{*} \\
\mathrm{AE}\end{array}$ & $\begin{array}{l}130909.211 \\
130908.101 \\
130908.693\end{array}$ & $\begin{array}{r}-0.360 \\
0.750 \\
0.158\end{array}$ & $\begin{array}{r}5 \\
-3 \\
6\end{array}$ & & \\
\hline & & & & & EA & 10073.161 & 0.843 & 8 & & & 18 & 8 & $11-18$ & 7 & 12 & $\begin{array}{l}\mathrm{AA} \\
\mathrm{EF}\end{array}$ & 130912.505 & & & 130912.411 & (20) \\
\hline 12 & 2 & $10-12$ & 1 & 11 & $\begin{array}{l}\mathrm{AA} \\
\mathrm{EE} \\
\mathrm{AE}\end{array}$ & $\begin{array}{ll}31 & 614.460 \\
31 & 614.401 \\
31 & 614.341\end{array}$ & $\begin{array}{l}0.059 \\
0.119\end{array}$ & $\begin{array}{l}-2 \\
-2\end{array}$ & 31614.381 & (5) & & & & & & $\begin{array}{l}\mathrm{EE} \\
\mathrm{EE} \\
\mathrm{EA} \\
\mathrm{AE}\end{array}$ & $\begin{array}{l}130912.004 \\
130913.095 \\
130911.541 \\
130912.379\end{array}$ & $\begin{array}{r}0.501 \\
-0.590 \\
0.964 \\
0.126\end{array}$ & $\begin{array}{r}-15 \\
11 \\
-5 \\
-26\end{array}$ & & \\
\hline 13 & 7 & $6-13$ & 6 & 7 & EA & $\begin{array}{r}31614.341 \\
113873.979\end{array}$ & 0.119 & -2 & 113873.903 & $(20)$ & 19 & 7 & $12-18$ & & 11 & $\begin{array}{l}\mathrm{AA} \\
\mathrm{EE}\end{array}$ & $\begin{array}{l}37746.816 \\
37747.399\end{array}$ & -0.583 & -8 & 37746.878 & (5) \\
\hline & & & & & $\begin{array}{l}\mathrm{EE} \\
\mathrm{EE}^{*}\end{array}$ & $\begin{array}{l}113874.332 \\
113873.272\end{array}$ & $\begin{array}{r}-0.353 \\
0.707\end{array}$ & $\begin{array}{l}-14 \\
-67\end{array}$ & & & 19 & 7 & $13-18$ & 8 & 10 & $\begin{array}{l}\mathrm{AA} \\
\mathrm{EE}\end{array}$ & $\begin{array}{l}37739.212 \\
37738.721\end{array}$ & 0.491 & 2 & 37739.268 & (5) \\
\hline 13 & 2 & $11-13$ & 1 & 12 & $\begin{array}{l}\mathrm{AA} \\
\mathrm{EE}\end{array}$ & $\begin{array}{l}35996.343 \\
35996.269\end{array}$ & 0.074 & -1 & 35996.244 & (5) & 19 & 8 & $11-19$ & & 12 & $\begin{array}{l}\mathrm{AA} \\
\mathrm{EE}\end{array}$ & $\begin{array}{l}130674.034 \\
130674.394\end{array}$ & -0.360 & -39 & 130673.957 & (20) \\
\hline & & & & & $\begin{array}{l}\mathrm{AE} \\
\mathrm{EA}\end{array}$ & $\begin{array}{l}35996.195 \\
35996.195\end{array}$ & $\begin{array}{l}0.148 \\
0.148\end{array}$ & $\begin{array}{l}-2 \\
-2\end{array}$ & & & 19 & 8 & $12-19$ & & 13 & $\begin{array}{l}\mathrm{AA} \\
\mathrm{EA}\end{array}$ & $\begin{array}{l}130681.842 \\
130680.888\end{array}$ & 0.954 & -33 & 130681.753 & (20) \\
\hline 13 & 2 & $12-13$ & 1 & 13 & $\begin{array}{l}\mathrm{AA} \\
\mathrm{EE} \\
\mathrm{AE} \\
\mathrm{EA}\end{array}$ & $\begin{array}{l}59064.963 \\
59064.867 \\
59064.777 \\
59064.777\end{array}$ & $\begin{array}{l}0.096 \\
0.186 \\
0.186\end{array}$ & $\begin{array}{l}5 \\
4 \\
4\end{array}$ & 59064.838 & (8) & & & & & & $\begin{array}{l}\mathrm{EA} \\
\mathrm{EE} \\
\mathrm{EE} \\
\mathrm{EA} \\
\mathrm{AE}\end{array}$ & $\begin{array}{l}130682.484 \\
130681.402 \\
130682.984 \\
130681.736\end{array}$ & $\begin{array}{r}-0.642 \\
0.440 \\
-1.142 \\
0.106\end{array}$ & $\begin{array}{r}4 \\
-26 \\
-26 \\
-39\end{array}$ & & \\
\hline 13 & 7 & $7-13$ & 6 & 8 & $\begin{array}{l}\mathrm{AA} \\
\mathrm{EE}\end{array}$ & $\begin{array}{l}113875.773 \\
113875.242\end{array}$ & 0.531 & 38 & 113875.651 & (20) & 20 & 9 & $11-19$ & 10 & 10 & $\begin{array}{l}\mathrm{AA} \\
\mathrm{EE}^{*}\end{array}$ & $\begin{array}{l}10735.425 \\
10735.570\end{array}$ & -0.145 & -13 & 10735.522 & $(5)$ \\
\hline 14 & 6 & $8-13$ & 7 & 7 & $\begin{array}{l}\mathrm{AA} \\
\mathrm{AE} \\
\mathrm{EE}\end{array}$ & $\begin{array}{l}10244.184 \\
10244.302 \\
10244.845\end{array}$ & $\begin{array}{l}-0.118 \\
-0.661\end{array}$ & $\begin{array}{l}-16 \\
-20\end{array}$ & 10244.267 & (5) & 20 & 9 & $12-19$ & 10 & 9 & $\begin{array}{l}\mathrm{AE} \\
\mathrm{AA} \\
\mathrm{AE}\end{array}$ & $\begin{array}{l}10735.570 \\
10735.425 \\
10735.570\end{array}$ & $\begin{array}{l}-0.145 \\
-0.145\end{array}$ & $\begin{array}{l}-10 \\
-10\end{array}$ & 10735.519 & (5) \\
\hline & & & & & $\mathrm{EE}^{*}$ & 10240.409 & 3.775 & -24 & & & 20 & 8 & $12-20$ & & 13 & AA & 130395.358 & & & 130395.269 & (20) \\
\hline 14 & 6 & $9-13$ & 7 & 6 & $\begin{array}{l}\mathrm{AA} \\
\mathrm{AE} \\
\mathrm{EE} \\
\mathrm{EE}^{*}\end{array}$ & $\begin{array}{l}10239.814 \\
10239.917 \\
10239.271 \\
10243.716\end{array}$ & $\begin{array}{r}-0.103 \\
0.543 \\
-3.902\end{array}$ & $\begin{array}{r}-1 \\
4 \\
0\end{array}$ & 10239.881 & (5) & & & & & & $\begin{array}{l}\mathrm{EE}^{*} \\
\mathrm{EE} \\
\mathrm{EA}^{*} \\
\mathrm{AE}\end{array}$ & $\begin{array}{l}130394.378 \\
130395.529 \\
130393.798 \\
130395.233\end{array}$ & $\begin{array}{r}0.980 \\
-0.171 \\
1.560 \\
0.125\end{array}$ & $\begin{array}{r}-19 \\
45 \\
-29 \\
-13\end{array}$ & & \\
\hline
\end{tabular}




\begin{tabular}{|c|c|c|c|c|c|c|c|c|c|c|}
\hline 14 & 7 & $7-14$ & 6 & 8 & $\begin{array}{l}\text { AA } \\
\text { EE } \\
\text { EA }\end{array}$ & $\begin{array}{l}113729.257 \\
113729.650 \\
113729.988\end{array}$ & $\begin{array}{l}-0.393 \\
-0.731\end{array}$ & $\begin{array}{l}-22 \\
-37\end{array}$ & 113729.177 & (20) \\
\hline 14 & 1 & $13-14$ & 01 & 14 & $\begin{array}{l}\text { AA } \\
\text { EE } \\
\text { AE } \\
\text { EA }\end{array}$ & $\begin{array}{l}60378.910 \\
60378.800 \\
60378.690 \\
60378.690\end{array}$ & $\begin{array}{l}0.110 \\
0.220 \\
0.220\end{array}$ & $\begin{array}{l}1 \\
2 \\
2\end{array}$ & 60378.763 & (8) \\
\hline 14 & 7 & $8-14$ & 6 & 9 & $\begin{array}{l}\text { AA } \\
\text { EE* } \\
\text { EE } \\
\text { EA }\end{array}$ & $\begin{array}{l}113733.557 \\
113734.077 \\
113733.030 \\
113732.559\end{array}$ & $\begin{array}{r}-0.520 \\
0.527 \\
0.998\end{array}$ & $\begin{array}{r}54 \\
6 \\
4\end{array}$ & 113733.441 & (20) \\
\hline 14 & 3 & $12-14$ & 21 & 13 & $\begin{array}{l}\text { AA } \\
\text { EE } \\
\text { AE } \\
\text { EA }\end{array}$ & $\begin{array}{ll}58 & 223.965 \\
58 & 223.890 \\
58 & 223.813 \\
58 & 223.813\end{array}$ & & $\begin{array}{l}0 \\
2 \\
2\end{array}$ & 58223.864 & (8) \\
\hline 14 & 9 & $6-15$ & 8 & 7 & $\begin{array}{l}\text { AA } \\
\mathrm{EE}^{*} \\
\mathrm{AE}\end{array}$ & $\begin{array}{l}16413.523 \\
16413.365 \\
16413.365\end{array}$ & $\begin{array}{l}0.158 \\
0.158\end{array}$ & $\begin{array}{l}6 \\
6\end{array}$ & 16413.418 & (5) \\
\hline 14 & 9 & $5-15$ & 8 & 8 & $\begin{array}{l}\mathrm{AA} \\
\mathrm{AE}\end{array}$ & $\begin{array}{l}16413.523 \\
16413.365\end{array}$ & 0.158 & 6 & 16413.419 & (5) \\
\hline 15 & 3 & $13-15$ & 21 & 14 & $\begin{array}{l}\text { AA } \\
\text { EE } \\
\text { AE } \\
\text { EA }\end{array}$ & $\begin{array}{ll}61 & 518.313 \\
61 & 518.230 \\
61 & 518.142 \\
61 & 518.142\end{array}$ & $\begin{array}{l}0.083 \\
0.171 \\
0.171\end{array}$ & $\begin{array}{l}0 \\
4 \\
4\end{array}$ & 61518.200 & (8) \\
\hline 16 & 3 & $13-16$ & 21 & 14 & $\begin{array}{l}\mathrm{AA} \\
\mathrm{EE} \\
\mathrm{AE} \\
\mathrm{EA}\end{array}$ & $\begin{array}{l}37226.626 \\
37226.571 \\
37226.515 \\
37226.515\end{array}$ & $\begin{array}{l}0.055 \\
0.111 \\
0.111\end{array}$ & $\begin{array}{l}-2 \\
-3 \\
-3\end{array}$ & 37226.552 & (5) \\
\hline 16 & 10 & $7-17$ & 9 & 8 & $\begin{array}{l}\mathrm{AA} \\
\mathrm{EE}^{*} \\
\mathrm{AE}\end{array}$ & $\begin{array}{l}16227.722 \\
16227.554 \\
16227.554\end{array}$ & $\begin{array}{l}0.168 \\
0.168\end{array}$ & $\begin{array}{r}12 \\
5\end{array}$ & 16227.608 & (5) \\
\hline 16 & 10 & $6-17$ & 9 & 9 & $\begin{array}{l}\mathrm{AA} \\
\mathrm{AE}\end{array}$ & $\begin{array}{l}16227.722 \\
16227.554\end{array}$ & 0.168 & J & 16227.611 & (5) \\
\hline
\end{tabular}

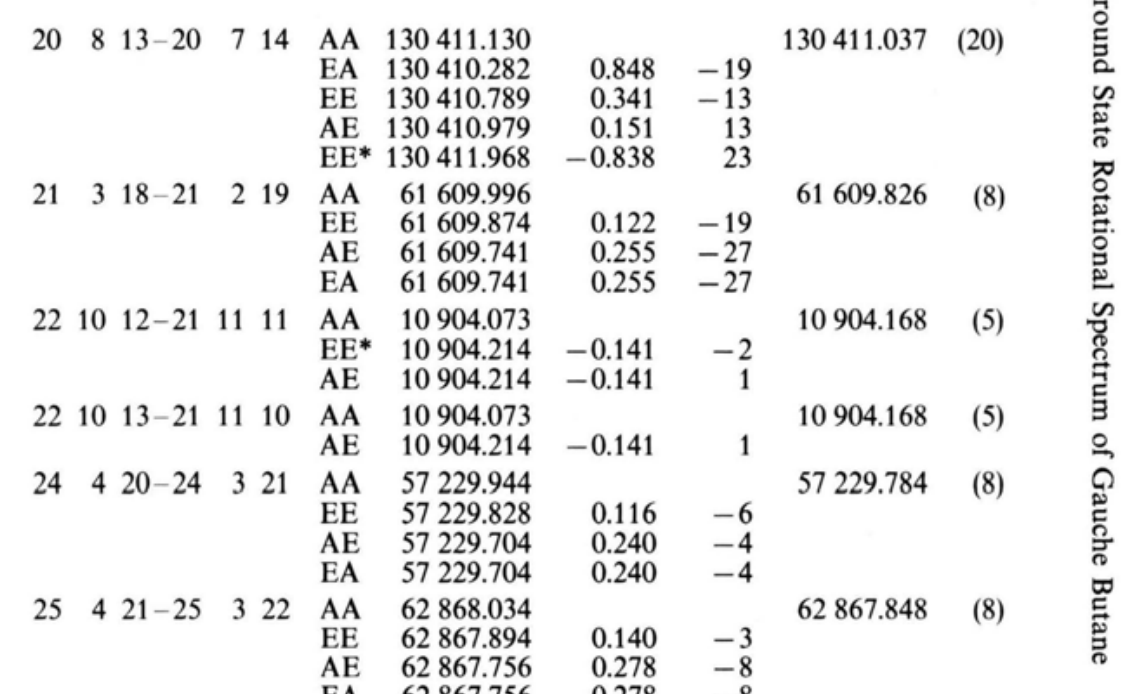

1) $W_{i}=\left(N / \Sigma_{i}\left(u_{i}^{-2}\right)\right) u_{i}^{-2}$ is the weight of $\Delta v_{i}, i=1,2, \ldots, N(=110)$. 
sures between 0.26 and $0.65 \mathrm{~Pa}$ ( 2 and $5 \mathrm{mTorr}$ ). All frequencies resulting from these measurements were determined by a least squares fit of the multiplet signals in the time domain to minimize overlapping effects $[16,17]$. The remaining transitions were recorded in Ulm with source modulation and time averaging techniques described previously [8]. The cell temperatures were chosen close to $-80^{\circ} \mathrm{C}$, the gas pressures below $3 \mathrm{mTorr}$ resulting in Doppler-limited line widths. The different degrees of accuracy in the fine structure splitting of the three groups of transitions were accounted for by appropriate weighting, see Table 1.

\section{Results and Discussion of the Internal Rotation Analysis}

The transition frequencies of gauche-butane chosen for the fine structure measurements were predicted with the rotational and centrifugal distortion constants given in [8]. First measurements in Kiel were made in the frequency range from 26.5 to $40 \mathrm{GHz}$. Some of the Q-branch transitions of the molecule showed triplet fine structures, e.g. $9_{18}-9_{09}$. These structures are typical for molecules possessing two equivalent internal rotors; hence it was attempted to analyze the fine structures by IAM, in the formulation of Woods $[18,19]$. First the Fourier coefficient $\omega_{1}(s)$ was fitted using the Q-branch transition splittings, the other internal rotation parameters were fixed to the values of gauche n-propyl fluoride [20]. Further predictions of the fine structure of transitions were made under consideration of the fitted Fourier coefficient. Finally, twenty transitions of several branches showing internal rotation splittings were used to determine the internal rotation parameters. It was possible to fit all of them with the exception of the moment of inertia of the methyl group $I_{\alpha}$. By adding the set of data obtained in Ulm in the frequency region above $40 \mathrm{GHz}$ it was possible to fit all parameters. All transitions with observed and calculated splittings are listed in Table 1. The internal rotation parameters were fitted with the program KC3IAM, written by Woods, modified by Kasten and Hübner. H. Hübner incorporated sextic centrifugal distortion constants and a normalized weighting factor in KC3IAM. The results of the fit and the rotational and centrifugal distortion constants used are listed in Table 2 under Fit I. In a second run we have omitted all transitions above $100 \mathrm{GHz}$. The resulting parameters and their
Table 2. Results of the internal rotation analysis. $\omega_{1}(s)$ : first Fourier coefficient, $I_{\alpha}$ : moment of inertia of the methyl group, $\Varangle(i, g)$ : angle between the internal rotation axis $i$ and the inertia axes $g=a, b, c, s$ : reduced barrier height, $F$ : reduced internal rotation constant, $V_{3}$ : barrier height of the internal rotation. Standard deviations are given in parentheses in units of the last significant digits. $\sigma$ : standard deviation of the fit, $\overline{\Delta v}$ : mean experimental splitting.

\begin{tabular}{|c|c|c|}
\hline & Fit $I^{*}$ & Fit II ** \\
\hline$\omega_{1}(s) \cdot 10^{5}$ & $-0.2943(62)$ & $-0.2965(47)$ \\
\hline$I_{\alpha}\left[\mathrm{amu} \cdot \AA^{2}\right]$ & $3.191 \quad(70)$ & $3.232(68)$ \\
\hline$\Varangle(a, i)\left[{ }^{\circ}\right]$ & $55.36 \quad(85)$ & $54.85 \quad(53)$ \\
\hline$\nless(b, i)\left[{ }^{\circ}\right]$ & $40.47 \quad(81)$ & $41.29 \quad(51)$ \\
\hline$\nless(c, i)\left[^{0}\right]$ & 71.7 & 71.2 \\
\hline$F[\mathrm{GHz}]$ & 166.2 & 164.2 \\
\hline & 76.02 & 75.95 \\
\hline$V_{3}\left[\mathrm{~kJ} \cdot \mathrm{mol}^{-1}\right]$ & 11.34 & 11.20 \\
\hline$V_{3}\left[\mathrm{kcal} \cdot \mathrm{mol}^{-1}\right]$ & $2.710 \quad(69)$ & $2.675 \quad(63)$ \\
\hline$\sigma[\mathrm{MHz}]$ & 0.017 & 0.005 \\
\hline$\overline{\Delta v}[\mathrm{MHz}]$ & 0.400 & 0.292 \\
\hline
\end{tabular}

Correlation coefficients Fit I:

$\begin{array}{lrrr}\omega_{1}(s) & 1.000 & & \\ I_{x} & -0.825 & 1.000 & \\ \hat{\lambda}_{+} & -0.192 & -0.232 & 1.000 \\ \lambda_{-} & -0.931 & 0.864 & -0.082\end{array}$
1.000

Fit II

$$
\begin{array}{lrrrr}
\omega_{1}(s) & 1.000 & & & \\
I_{\alpha} & -0.954 & 1.000 & & \\
\hat{i}_{+} & 0.154 & -0.329 & 1.000 & \\
i_{-} & -0.985 & 0.973 & -0.247 & 1.000 \\
i_{+}=\cos ^{2} \Varangle(a, i)+\cos ^{2} \Varangle(b, i)=1-\cos ^{2} \Varangle(c, i) & \\
i_{-}=\cos ^{2} \Varangle(a, i)-\cos ^{2} \Varangle(b, i) &
\end{array}
$$

Rotational and centrifugal distortion constants used in the analysis:

\begin{tabular}{lcc}
$A$ & $13211.92105 \mathrm{MHz}$ \\
$B$ & $4761.72373 \mathrm{MHz}$ \\
$C$ & $4059.68936 \mathrm{MHz}$ \\
$\Delta_{J}$ & $4.67201 \mathrm{kHz}$ \\
$\Delta_{J K}$ & $-20.2086 \mathrm{kHz}$ \\
$\Delta_{K}$ & $62.475 \mathrm{kHz}$ \\
$\delta_{J}$ & $1.46428 \mathrm{kHz}$ \\
$\delta_{K}$ & $12.0467 \mathrm{kHz}$ \\
$\Phi_{J K}$ & $0.0191 \mathrm{~Hz}$ \\
$\Phi_{K J}$ & $-0.782 \mathrm{~Hz}$ \\
$\Phi_{K}$ & $3.140 \mathrm{~Hz}$ \\
$\varphi_{J}$ & $0.00315 \mathrm{~Hz}$ \\
$\varphi_{J K}$ & $-0.0927 \mathrm{~Hz}$ \\
\hline
\end{tabular}

* includes all data of Table 1.

** excluding $\mathrm{mm}$ wave data $>100 \mathrm{GHz}$.

standard deviations (Fit II) are also given in Table 2. They compare well with the results of the first calculation, but the correlation matrix indicates stronger dependencies. We consider, therefore, the parameters obtained with the complete data set (Fit I) as the preferable solution. 
Table 3. Internal rotation parameters of some compounds with the same configuration of the alkyl group as gauche butane. Standard deviation of the parameters in parentheses, assumed values in square brackets.

\begin{tabular}{|c|c|c|c|}
\hline & $\begin{array}{l}\mathrm{CH}_{3} \mathrm{CH}_{2} \mathrm{CH}_{2} \mathrm{~F} \\
{[20]}\end{array}$ & $\begin{array}{l}\mathrm{CH}_{3} \mathrm{CH}_{2} \mathrm{CH}_{2} \mathrm{CN} \\
{[21]}\end{array}$ & $\begin{array}{l}\mathrm{CH}_{3} \mathrm{CH}_{2} \mathrm{CH}_{2} \mathrm{CH}_{3} \\
\text { [this work] }\end{array}$ \\
\hline$\omega_{1}(s) \cdot 10^{5}$ & $-0.2810(26)$ & $-0.0891(41)$ & $-0.2943(62)$ \\
\hline$I_{\alpha}\left[\mathrm{amu} \cdot \AA^{2}\right]$ & 3.168 (35) & [3.139] & $3.191 \quad(70)$ \\
\hline$\nless(a, i)\left[{ }^{\circ}\right]$ & $55.54 \quad(40)$ & $72.9 \quad$ (25) & $55.36 \quad(85)$ \\
\hline$\nless(b, i)\left[^{\circ}\right]$ & $38.74 \quad(38)$ & 25.6 & $40.47 \quad 81)$ \\
\hline$\Varangle(c, i)\left[^{\circ}\right]$ & 74.49 & 71.6 & 71.7 (17) \\
\hline$\hat{F}[\mathrm{GHz}]$ & 168.0 & 164.89 & 166.2 \\
\hline & 76.505 (95) & 87.85 & $76.02 \quad(20)$ \\
\hline$V_{3}[\mathrm{~kJ} / \mathrm{mol}]$ & 11.54 (15) & $13.01 \quad$ (10) & $11.34 \quad$ (29) \\
\hline$V_{3}[\mathrm{kcal} / \mathrm{mol}]$ & $2.758 \quad(35)$ & 3.107 (24) & 2.710 (69) \\
\hline
\end{tabular}

For comparison, the internal rotation parameters of gauche n-propyl fluoride [20] and gauche butyronitrile [21] are listed in Table 3. An ab initio calculation of the potential height $V_{3}$ of gauche-butane was accomplished using the procedure discribed by Aljibury, Snyder, and Strauss [22]. First the equilibrium structure and energy were computed. The resulting methyl rotation value, $\alpha=\alpha_{0}$, was taken as reference for further rotations, the corresponding energy $E_{0}$ as zero point for the calculations of energy differences. In the second step one of the methyl groups was rotated by changing the angle $\alpha$, while the other was fixed to $\alpha_{0}$. In the third step every energy $E(\alpha)$ was calculated with 'full structural relaxation', meaning that all bond lenghts and bond angles with the exception of $\alpha$ and $\alpha_{0}$ were fitted again. The following results were obtained ( $\Delta E$ is the energy difference between $E_{0}$ and $E(\alpha))$ :

\begin{tabular}{lccll}
\hline$\alpha$ & $15^{\circ}$ & $30^{\circ}$ & $45^{\circ}$ & $60^{\circ}$ \\
$\Delta E\left[\mathrm{~kJ} \cdot \mathrm{mol}^{-1}\right]$ & 1.675 & 5.918 & 10.331 & 12.090 \\
\hline
\end{tabular}

The energy variation as a function of $\alpha$ was used to fit $V_{3}$ to the expression $\Delta E=0.5 V_{3}(1-\cos 3 \alpha)$ by the method of least squares. The result $V_{3}=$

[1] A. L. Verma, W. F. Murphy, and H. J. Bernstein, J. Chem. Phys. 60, 1540 (1974).

[2] S. S. Chen, R. C. Wilholt, and B. J. Zwolinski, J. Phys. Chem. Ref. Data 4, 859 (1975).

[3] D. A. C. Compton, S. Montero, and W. F. Murphy, J. Phys. Chem. 84, 3587 (1980).

[4] R. K. Heenan and L. S. Bartell, J. Chem. Phys. 78, 1270 (1983).

[5] S. Kint, J. R. Scherer, and R. G. Snyder, J. Chem. Phys. 73, 2599 (1980).
$12.055(63) \mathrm{kJ} \cdot \mathrm{mol}^{-1}$ is gratifyingly close to the experimental potential height of $11.34(29) \mathrm{kJ} \cdot \mathrm{mol}^{-1}$ given in Table 2. All calculations were made with the program GAUSSIAN 86 employing the $4-31 \mathrm{G}$ basis set [23].

These results and the overall agreement between the observed and calculated fine structure splittings in Table 1 convincingly show that the latter are solely caused by internal rotation of the methyl groups. In some cases, the deviation between experimental and calculated splittings increases the tolerable amount compared with the estimated uncertainty. Considering the large range of $K_{-}$-values involved - up to 12 - it may be possible that this is caused by centrifugal distortion effects in $V_{3}$ and $I_{\alpha}$.

\section{Acknowledgements}

W. Majer and H. Kästle have contributed in recording the fine structures in the mm range. We also thank the members of our groups for help and discussions, the Deutsche Forschungsgemeinschaft, the Land Schleswig-Holstein and Baden-Württemberg and the Fonds der Chemie for funds. The ab initio calculations were carried out at the computer center of the University Kiel.

[6] G. Gassler and W. Hüttner, Z. Naturforsch. 45a, 113 (1990).

[7] W. Hüttner, W. Majer, and P. Wirsing, Chem. Phys. Lett. submitted.

[8] W. Hüttner, W. Majer, and H. Kästle, Mol. Phys. 67, 131 (1989).

[9] J. K. G. Watson, Aspects of Quartic and Sextic Centrifugal Effects on Rotational Energy Levels, in: "Vibrational Spectra and Structure", J. R. Durig Ed., Elsevier, New York 1977, p. 39. 
[10] H. D. Stidham and J. R. Durig, Spectrochim. Acta 42 a, 105 (1986).

[11] K. Raghavachari, J. Chem. Phys. 81, 1383 (1984).

[12] N. L. Allinger, R. S. Grev, B. F. Yates, and H. F. Schaefer III, J. Amer. Chem. Soc. 112, 114 (1990).

[13] G. Bestmann, H. Dreizler, H. Mäder, and U. Andresen, Z. Naturforsch. 35a, 392 (1980).

[14] G. Bestmann and H. Dreizler, Z. Naturforsch. 37 a, 58 (1982).

[15] Ch. Keussen, N. Heineking, and H. Dreizler, Z. Naturforsch. 44 a, 215 (1989).

[16] I. Merke and H. Dreizler, Z. Naturforsch. 43a, 196 (1988).

[17] J. Haekel and H. Mäder, Z. Naturforsch. 43a, 203 (1988).
[18] R. C. Woods, J. Mol. Spectrosc. 21, 4 (1966).

[19] R. C. Woods, J. Mol. Spectrosc. 22, 49 (1967).

[20] W. Kasten and H. Dreizler, Z. Naturforsch. 41 a, 955 (1986).

[21] K. Vormann and H. Dreizler, Z. Naturforsch. 43a, 338 (1988).

[22] A. L. Aljibury, R. G. Snyder, and H. L. Strauss, J. Chem. Phys. 84, 6872 (1986).

[23] GAUSSIAN 86, M. J. Frisch, J. S. Brinkley, H. B. Schlegel, K. Raghavachari, C. F. Melius, R. L. Martin, J. J. P. Stewart, F. W. Bobrowicz, C. M. Rohlfing, L. R. Kahn, D. J. Defrees, R. Seeger, R. A. Whiteside, D. J. Fox, E. M. Fleuder, and J. A. Pople, Carnegie-Mellon Quantum Chemistry Publishing Unit, Pittsburgh PA, 1984. 